\title{
磁力支持天秤による切り立った底部を有する機体のBase 圧補正に関する研究*1 An Experimental Study on Base Pressure Correction for Bluff-Base Bodies Using Magnetic Suspension and Balance System
}

\author{
只 熊 憲 治*2 $\cdot$ 麻 生 茂*3 $\cdot$ 谷 泰 寛*3 $\cdot$ 溝口 也寸志*4 岡 田 卓 三*4 \\ Kenji Tadakuma, Shigeru Aso, Yasuhiro Tani, Yasushi Mizoguchi and Takumi Okada
}

Key Words : Base Pressure Correction, MSBS, Sting Interference, Bluff-Base Body

\begin{abstract}
An experimental study on validity and improvement of base pressure correction for a bluff-base body with hemisphere nose using MSBS (Magnetic Suspension and Balance System) has been conducted. Force and pressure distribution data on the model base were examined for several parameters; angles of attack 0-7.5 ${ }^{\circ}$, Reynolds number $R e_{D}=7.6 \times 10^{4}$, with or without a sting and diameters of the sting. These results showed that the base pressure correction using the pressure data near the sting could have validity at the case of $0^{\circ}$ of angle of attack only. Besides we could propose a new accurate method to calculate base-pressure axis forces.
\end{abstract}

記号

$C_{p_{\mathrm{b}}}$ : base 压力係数

$C_{X b_{\text {nst }}}:$ スティング支持なしでの base 圧力による軸力係数

$C_{X b_{\mathrm{st}}}$ : スティング支持時，面積 $S_{\mathrm{bc}}$ にかかる base 圧力 による軸力係数

$D_{\mathrm{m}}:$ 模型底面直径

$D_{\mathrm{s}}:$ スティング直径

$F_{\mathrm{A}}:$ 軸力

$F_{\mathrm{AF}}:$ forebody 軸力

$p_{\mathrm{b}}$ : base 圧

$p_{\mathrm{c}}:$ cavity 圧

$p_{\mathrm{t}}(\alpha)$ : 迎角 $\alpha$ における模型頭部全圧孔計測による全圧

$p_{\infty}:$ 主流静圧

$R e_{D}:$ レイノルズ数 (代表長 $D_{\mathrm{m}}$ )

$S_{\mathrm{b}}:$ 模型底面積

$S_{\mathrm{bc}}: S_{\mathrm{b}}-S_{\mathrm{st}}$ (第 5 図参照)

$S_{\mathrm{st}}$ : スティング挿入孔面積 (第 5 图参照)

$S_{\mathrm{cs}}$ : cavity 面積 (第 5 図参照)

$\alpha:$ 迎角

1. 序論

近年, 完全再使用型宇宙往還機 (FRLV : Fully Reusable Launch Vehicle) の開発が進められており, 光の機体は切 り立った底部を有するものや，re-entry から着陸する間を 滑空して降下するものが多い. 兴のような宇宙往還機の開 発においては, 特に, 機体の空気力を正確に求める必要が

*1 (C) 2005 日本航空宇宙学会

平成 17 年 6 月 8 日原稿受理

*2 九州大学大学院工学府航空宇宙工学専攻

*3 九州大学大学院工学研究院航空宇宙工学部門

$* 4$ 三菱重工業 (株) 神戶造船所
ある

乥こで, 我々は，このような FRLVに代表される滑空飛 行を行う切り立った底部を有する機体を対象とし, 空気力 の精度向上のために, 風洞試験で行われる base 圧補正法に 着目し, 弚の妥当性及び全機軸力推定方法について検討を 行った。

base 圧補正とは，模型を後方からスティング支持する風 洞試験において空気力を取得する際，模型底面にかかる力 が零である全機軸力，つまり，forebody 軸力を求めるため に行われる ${ }^{1 \sim 4)}$. 具体的には, base 圧補正は, 模型底面の スティング付近の base 圧を取得し, 弚れが模型底面全体に かかると仮定し, 乥の力を内挿型スティング天秤などで得 られた空気力から差し引くことによって行われる補正法で ある ${ }^{1,3)}$. 第 1 図に base 圧補正について示す . また, forebody 軸力算出について第 $(1)$ 式に示す ${ }^{1 \sim 3)}$. ここで, $F_{\mathrm{AF}}$ は forebody軸力， $F_{\mathrm{A}}$ は天秤などによって計測された軸力， $p_{\mathrm{b}}$ は base 圧, $p_{\infty}$ は一樣流静圧， $S_{\mathrm{b}}$ は模型底面積である。 場合によっては, スティングを内捙するために空けた孔の 中 (cavity) の cavity 圧を計測し, 光れも含めて補正する こともある ${ }^{5,6)}$.

$$
F_{\mathrm{AF}}=F_{\mathrm{A}}+\left(p_{\mathrm{b}}-p_{\infty}\right) S_{\mathrm{b}}
$$

最終的に求めたい軸力は forebody 軸力ではなく全機軸 カであり，一般に，尾部を含む模型で幾つかの支持法を組 み合わせて, 空気力を測定し, 全機軸力を推定する.一方， 今回の対象である切り立った底部を有する機体の場合は， forebody 軸力に, 別途推算した base 抵抗を加算して全機 軸力を推定する方法も使用されている1,2).

これらの base 圧補正及び切り立った底部を有する機体に 関する全機軸力推定について，次の検討課題が存在すると 考えられる . 
1) base 圧補正について, forebody 軸力を算出するために 用いられる base 圧が模型底面全体にかかるという仮定 の妥当性の検討 。つまり，上述の base 圧補正が模型底 面にかかる力を零にする補正であるかについての検討

2) 滑空飛行する切り立った底部を有する機体の全機軸力推 定のための base 抵抗推算方法についての検討 .

第 1 の検討課題については, スティング装着時の base 圧分布を調べればよい，例として, $\mathrm{Kavanau}^{7)}$ は, 弚の分 布が迎角 $0^{\circ}$ で非一樣であることを示している．弚の他に， 樣々なスティング形状, 模型後部形状及び fin の有無に対 する空気力及び base 圧への影響を報告した例など10 16) は， 多数存在する . しかしながら , スティング装着時のbase 圧 分布の一樣性について詳細に調べた例はほとんどない．

第 2 の検討課題である切り立った底部を有する機体の全 機軸力推定のための base 抵抗推算方法については，

1) 過去の計測結果による実験式や解析值を用いて推算する 方法 $7 \sim 9,12)$

2) 別途，風洞試験 ${ }^{17 \sim 19)}$ や数值計算 ${ }^{20,21)}$ により算出する 方法

があると考えられる．しかしながら，過去の計測結果によ る方法の場合，基になるデータに支持干渉を含んでいるも のや迎角 $0^{\circ}$ のみの検討であるものも多く，宇宙往還機のよ うな機体に適用するのは難しい，また，別途，風洞試験や 数値計算を行うにはコスト及び時間を要する.

また，支持干涉がない状態で実験を行う方法として，磁 力支持天秤を用いる方法や飛行試験がある. Britcher ら ${ }^{10)}$ やStoney ${ }^{22)}$ は光れ光れ磁力支持天秤，飛行試験を利用し， スティング有無による base 圧や base 抗力などを調べた結 果を報告している。しかしながら，弚れらの報告も弚れ年 れの速度域に対し，単一の迎角でデータを取得したもので ある. 兴のため, 全機軸力推定のための base 抵抗推算方法 を考えるためには，支持干渉がない状態において，より体 系的なデータ取得が望まれる。

そこで，著者らは，これら 2 つの検討課題に対して，1) スティング支持状態での模型底面における base 圧分布につ いて調査し, base 圧補正が模型底面にかかる力を零にする 補正であるかについて検討すること，及び，2) 支持干渉が ない状態を作り出し，より体系的なデータ取得を行うこと によって全機軸力推定のための base 抵抗推算方法を確立す ること，を目的とし，研究を行った。これらにより，base 圧補正の妥当性の確認及び支持干渉のない base 圧データ を基にした，全機軸力推定のための base 抵抗推算を行うこ とができるため, 風洞試験における空気力の精度向上が見 込まれる.

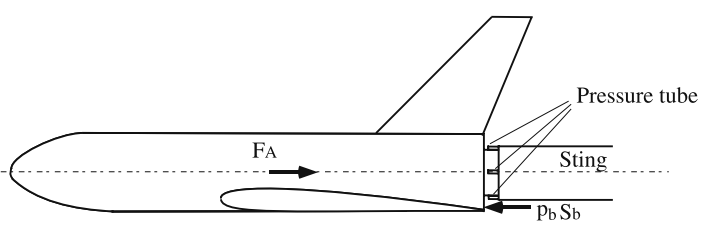

第1図 base 压補正
本研究では, 支持干渉がない状態を実現するために磁力 支持天秤を用い，切り立った底部を有する機体を対象とし， スティングの有無, スティング径変化及び迎角変化に対す る base 圧分布について調べる．本論文では低速域における 結果について報告する．

\section{2. 実験装置と方法}

2.1 風洞と天秤 使用した風洞は, 九州大学所有の $300 \mathrm{~mm} \times 300 \mathrm{~mm}$ の測定部を持つ吹き出し式低速風洞で ある.また，支持干渉がない状態で実験を行うために，三 菱重工業 (株) 神戶造船所より借用した $300 \mathrm{~mm} \times 300 \mathrm{~mm}$ の測定部を持つ磁力支持天秤 (MSBS : Magnetic Suspension and Balance System, 以降 MSBS と呼ぶ）を用いた . コイル配置やコイル電流制御方法は JAXA 所有の 5 軸制 御磁力支持天秤と同樣である ${ }^{23)}$. これらの吹き出し式風洞 と MSBS を連結させ, 実験を行った . 鈍頭模型浮上の樣子 を第 2 図に示す。

連結した風洞の乱れ強さは $0.7 \%$ 以内であり，測定部断面 の動圧は平均動圧に対して - $1.4 〜 1.0 \%$ の範囲内で一樣性 を有している。

2.2 模型と base 圧測定方法 実験に使用した模型を 第 3 図に示す .頭部が半球で胴体部が円柱の鈍頭模型であ る. 模型中心付近の黑線は, MSBS 付属のカメラによる模 型位置検出に用いる。模型材料は，磁場に影響を与えない ように，主にアルミニウムとアクリルを使用している．第 3 图 (b) に模型の構成品について示す.模型を浮上させる ために直径 $20 \mathrm{~mm}$ ，長さ $120 \mathrm{~mm}$ のアルニコ磁石を模型内 部に収納及び固定した . また，base 圧を計測できるように， 無線圧力計測システムを収納し, 模型底部に直径 $0.5 \mathrm{~mm}$ の静圧孔を設けてある .

無線圧力計測システムとは, 赤外線通信モジュール, 電 源，H8 マイコン及び微差圧センサで構成され，測定され た差圧データを赤外線により風洞外部へ送信するシステム である.MSBS により浮上した模型周りの圧力を無線で計 測する方法は他にも Britcher ら ${ }^{10)}$ や澤田ら ${ }^{24)}$ の例がある . 磁場が無線圧力計測システムに与える影響を調査するため に , 模型浮上による磁場が存在する状態と存在しない状態 において, 基準となる微差圧計 (測定レンジ 0〜 500 Pa) を

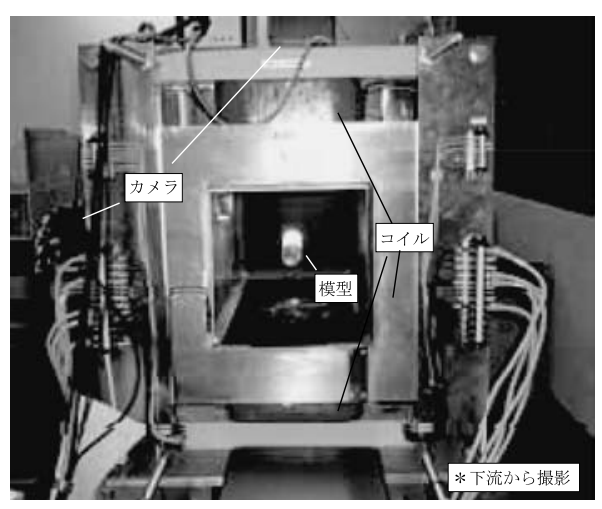

第 2 図 鈍頭模型浮上の樣子 
用いて較正を行った . 谷の結果 , 較正結果の不確かさは磁場 の有無にかかわらず $\pm 1.5 \mathrm{~Pa}$ (基準となる微差圧計のフルス ケールに対して $\pm 0.3 \%)$ 以内であり, 模型浮上による磁場 の影響はないと判断できる.なお，不確かさ解析は，2.4 節 に示す方法と同樣であり，光の区間は $95 \%$ 信頼区間を表す 測定する差圧は，迎角 $\alpha$ のときの模型頭部全圧孔計測 による全圧 $p_{\mathrm{t}}(\alpha)$ と base 圧 $p_{\mathrm{b}}$ との差圧であり，求めたい base 圧の圧係数とは異なる. 求めたい base 圧の圧力係 数 $C_{p_{\mathrm{b}}}$ は第 $(2)$ 式より算出される .ここで, $f(\alpha)$ は迎角に よる模型頭部全圧孔により計測される全圧への影響を補正 する項であり，迎角 $0^{\circ}$ のときの模型頭部全圧孔計測による 全圧 $p_{\mathrm{t}}(0)$ を用いて表すと第 $(3)$ 式となる . これは base 圧 を計測する実験の前に明らかにしておく必要がある．具体 的には, 迎角 $0 \sim 7.5^{\circ}$ における模型頭部全圧孔による全圧 を測定し，弚の值を $f(\alpha)$ の算出に用いた．关の結果を第 4 図に示す .なお，エラーバーは，2.4 節に示す不確かさ解 析と同樣な方法で求め，95\%信頼区間を表す。

$$
\begin{aligned}
C_{p_{\mathrm{b}}} & =\frac{p_{\mathrm{b}}-p_{\infty}}{q_{\infty}}=1-\frac{p_{\mathrm{t}}(\alpha)-p_{\mathrm{b}}}{q_{\infty}}+f(\alpha) \\
f(\alpha) & =\frac{p_{\mathrm{t}}(\alpha)-p_{\mathrm{t}}(0)}{q_{\infty}}
\end{aligned}
$$

測定した動圧などのデータに対して, 測定部壁面の境界層 によって生じる静圧勾配を考慮し，さらに，固体壁測定部に 対する閉塞効果補正 (solid blockage 及び wake blockage)

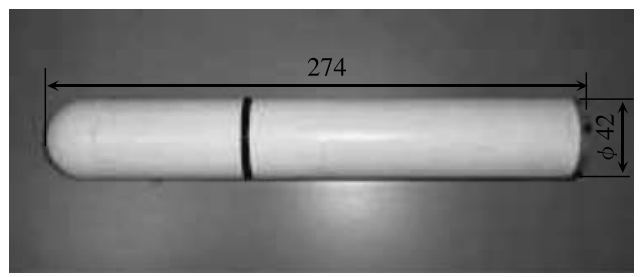

(a) 模型

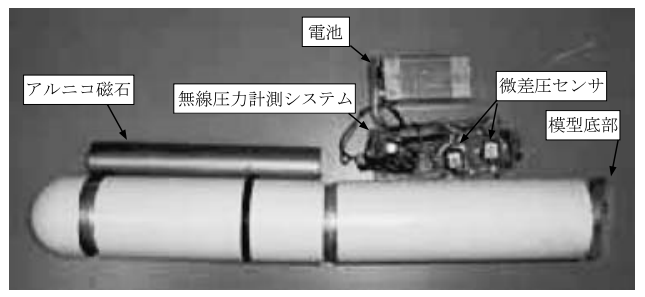

(b) 模型構成品

第3 図 実験模型

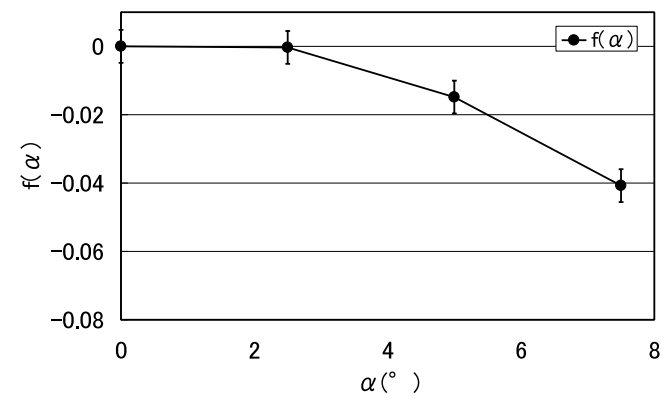

第 4 図 迎角による模型頭部全圧孔により計測される全圧への影響
を行った 25 28) .

2.3 実験条件 まず, 本論文における base 面積 , スティ ング挿入孔面積及び cavity 面積の定義について第 5 図に示 す. $S_{\mathrm{bc}}$ は模型底面積 $S_{\mathrm{b}}$ からスティング挿入孔面積 $S_{\mathrm{st}}$ を 引いた面積である．また， $S_{\mathrm{cs}}$ は cavity 面積であり，スティ ング挿入孔面積 $S_{\mathrm{st}}$ からスティング断面積を除いた面積で ある.スティング支持時における $S_{\mathrm{bc}}$ ，または，スティン グ支持のない状態における模型底面積 $S_{\mathrm{b}}$ にかかる圧力を base 圧， $S_{\mathrm{cs}}$ にかかる圧力を cavity 圧と呼ぶこととする .

実験は, base 圧分布測定を, スティングの有無，スティ ング径変化及び迎角変化の場合において行った . 実験ケー スを第 6 図に示す.第 6 图 (a) はスティング支持がない場 合であり，base 形状は flat である ．底部に base 圧孔を設 け，底部を $45^{\circ}$ ずつロール方向へ回転させることによって base 圧データを取得した . 兴の他のケースも同樣である . 第 6 図 (b) 及び (c) はスティング支持の場合であり，スティ ングを通すための深さ $15 \mathrm{~mm}$ のスティング挿入孔を設け

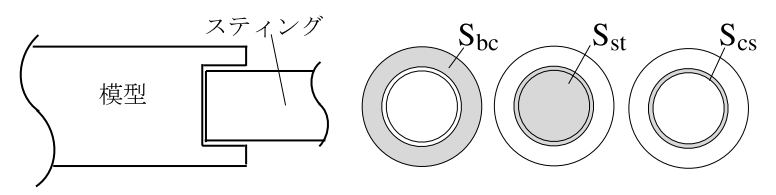

第 5 図 base 面積，スティング挿入孔面積及び cavity 面積の定義
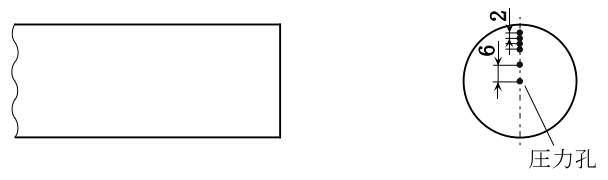

(a) スティング支持がない場合

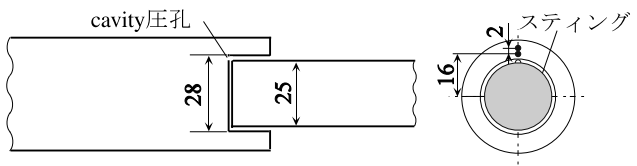

(b) スティング径 $25 \mathrm{~mm}$
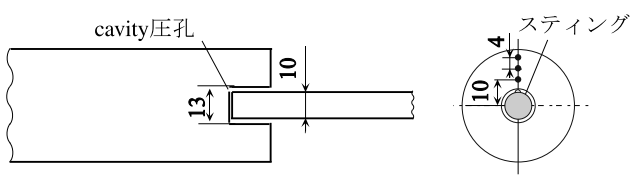

(c) スティング径 $10 \mathrm{~mm}$

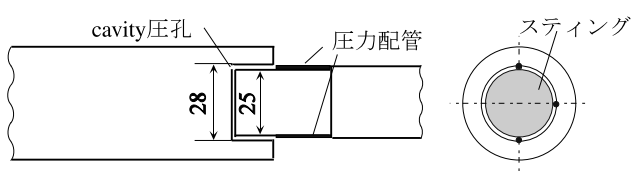

(d) スティング径 $25 \mathrm{~mm}$ 圧力配管あり

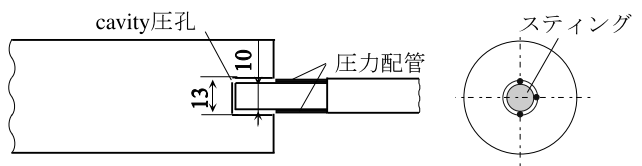

(e) スティング径 $10 \mathrm{~mm}$ 圧力配管あり

第 6 図 実験ケース (○：base 圧孔，○：cavity 圧孔） 
ている.第 6 図 $(\mathrm{d})$ 及び $(\mathrm{e})$ は , 第 1 図に示したものと同 樣に, base 圧補正に用いる base 圧を取得する場合である スティング周りの模型底面近くに base 圧孔と同じ径の圧力 管 (外径 $1 \mathrm{~mm}$, 内径 $0.5 \mathrm{~mm}$ のステンレス管) を模型底 面に向かって上下及び右の 3 点配置し，谷の位置での base 圧を取得した . スティング径及びスティング挿入孔径は光 れ光れ第 6 図 (b) 及び (c) と同樣である .この圧力配管に よる base 圧も他の base 圧と同樣に模型全圧孔による全圧 との差圧として計測し, 弚の圧力係数は第 $(2)$ 式及び第 $(3)$ 式により算出した .なお，第 6 図中の圧力計測孔は, 光の 位置を分かりやすくするために実物の比より大きく描いて いる.また, cavity 圧も光れ光れのケースにおいて取得し ている.

スティングについて第 7 図に示す . スティングはアルミ 管を用い，支柱と模型底面までの距離はいずれの場合も $460 \mathrm{~mm}$ に固定した . 支柱は, 幅 $9 \mathrm{~mm}$, 長さ $40 \mathrm{~mm}$, 高

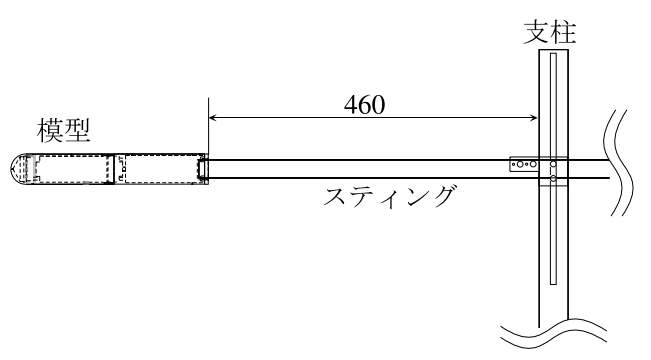

第 7 図 スティング概略図

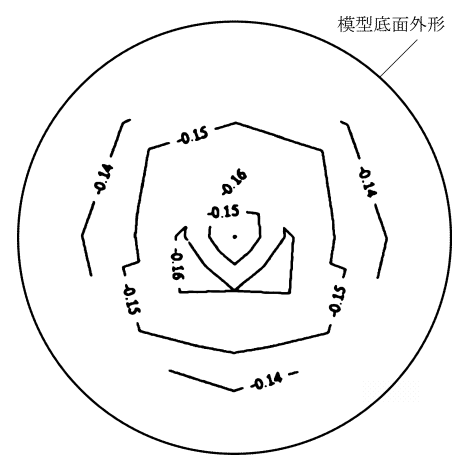

(a) $\alpha=0^{\circ}$ スティング支持なし

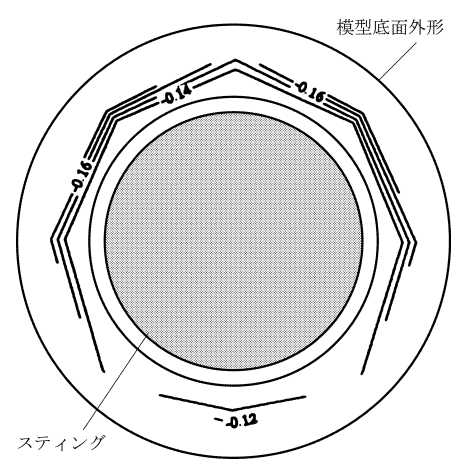

(c) $\alpha=7.5^{\circ}$ スティング支持あり (径 $25 \mathrm{~mm}$ )
さ $559 \mathrm{~mm}$ である . なお , スティングの模型側の端は , ア クリル板でふたをしている .

風速は $27 \mathrm{~m} / \mathrm{s}$ とした . 測定した迎角範囲は，MSBSに よる模型検知範囲の制限を考慮して $0^{\circ}$ から $7.5^{\circ}$ までとし た. 今回の模型において，光れ以上の迎角になると模型の 磁気浮上が困難となる . 模型直径 $D_{\mathrm{m}}(=0.042 \mathrm{~m})$ を代表 長としたレイノルズ数 $R e_{D}$ は, $7.6 \times 10^{4}$ である .

2.4 不確かさについて 取得したデータを適切に評価 するために不確かさ解析を行った . 不確かさ解析は, Kline らなど ${ }^{29,30)}$ の方法を基に行い，95\%の信頼を有する不確か さ区間をグラフ上にェラーバーとして示している .

\section{3. 実験結果と考察}

3.1 base 压分布に関する結果と考察 第 8 図に模型底 面 base 圧孔より計測された base 圧の分布を示す. 今回の 計測では横滑り角 $0^{\circ}$ であり，流れ場は $X-Z$ 平面に対称と 考えられるので, 右半面において計測したbase 圧を左半面 に同樣に与え，底面全体の圧力分布として示している．第 8 図 (a)より, 迎角 $0^{\circ}$ におけるスティング支持なしの base 圧分布は同心円状の分布を示し，ほぼ一樣な分布であるこ とが分かる、第 8 図 (b)より，迎角を有すると，底面上部 の base 圧は低く，下部は高くなり，光の分布が一樣でなく なっていることが分かる. また，弚の值は迎角 $0^{\circ}$ の base 圧と比べ，低くなる．スティング支持した場合，第 8 図 (c) 及び $(\mathrm{d})$ より，支持しない場合と比べて， base 圧が全体的 に高くなっていることが分かる．また，径 $25 \mathrm{~mm}$ 及び径

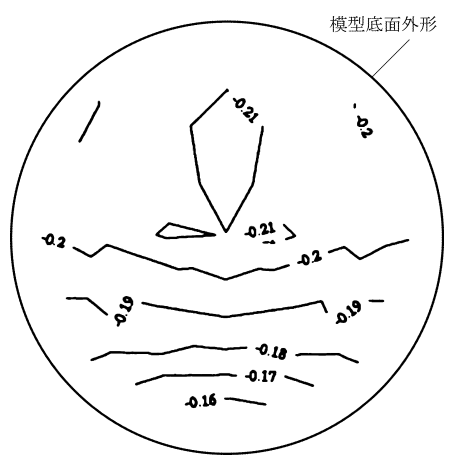

(b) $\alpha=7.5^{\circ}$ スティング支持なし

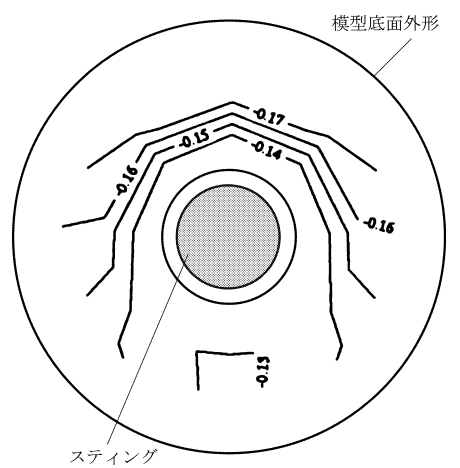

(d) $\alpha=7.5^{\circ}$ スティング支持あり (径 $10 \mathrm{~mm}$ ) 
$10 \mathrm{~mm}$ のどちらにおいても，底面上部は低い值を，下部は 高い值を示し, 支持がない場合の base 圧分布と同樣な傾向 を示している。

3.2 base 圧補正の妥当性に関する結果と考察 次に base 圧補正の妥当性について議論する . 本論文では, base 圧や cavity 圧によって底面にかかる軸力成分を無次元化し たものについて「base 圧による軸力係数」などと呼ぶこと にする.第 9 図にスティング支持時の base 圧による軸力 係数を示す. スティング支持時の base 圧による軸力係数 $C_{X b_{s t}}$ とは，第 (4) 式によって与えられ，スティング支持 時において, base 圧により面積 $S_{\mathrm{bc}}$ にかかる力を動圧と模 型底面積 $S_{\mathrm{b}}$ で無次元化したものである . 面積の名称につ いては第 5 図と同樣である . 光れらの軸力係数の向きは第 9 図中に示すように機軸下流方向を正とする .

$$
C_{X b_{\mathrm{st}}}=-\int_{S_{\mathrm{bc}}}\left(p_{\mathrm{b}}-p_{\infty}\right) \mathrm{d} S / q_{\infty} S_{\mathrm{b}}
$$

グラフ中の「スティング径 $25 \mathrm{~mm} 」$ 及び「スティング径 $10 \mathrm{~mm}\lrcorner$ は, 模型底面に設けられた静圧孔から取得したbase 圧分布を用いて，第 (4) 式より与えられる．また，「スティ ング径 $25 \mathrm{~mm}$ 圧力配管」及び「スティング径 $10 \mathrm{~mm}$ 圧力 配管」は，同樣に第 (4) 式によって与えられ，模型底面ス ティング付近の base 圧が面積 $S_{\mathrm{bc}}$ 全体にかかると仮定し て算出した base 圧による軸力係数である.

第 9 図より，スティング支持の場合において，「スティン

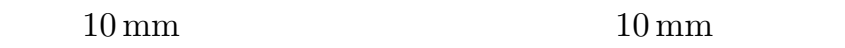
て，光の差はほとんどない 、「スティング径 $25 \mathrm{~mm}$ 圧力配 管」と「スティング径 $25 \mathrm{~mm}$ については，迎角が大きく なると，弚の差がわずかではあるが大きくなっている .

第 10 图及び第 11 図に关れ光れのケースにおける base 圧の分布を示す．弚れ光れ第 10 图は迎角 $0^{\circ}$, 第 11 図は迎 角 $7.5^{\circ}$ の base 圧分布である. 迎角 $0^{\circ}$ の場合, 流れ場が 軸対称であると考え， $z$ 軸方向のみの base 圧を計測した . 第 10 図より，スティング支持した場合の模型底面 base 圧 は，平坦な分布を示しており， base 圧分布はほぼ一樣であ ると考えられる．また，圧力配管による base 圧と模型底面 base 圧孔によって計測された base 圧の值もほぼ等しいこ とが分かる.

第 11 図 (a)より，迎角 $0^{\circ}$ の場合と同樣に，「スティング

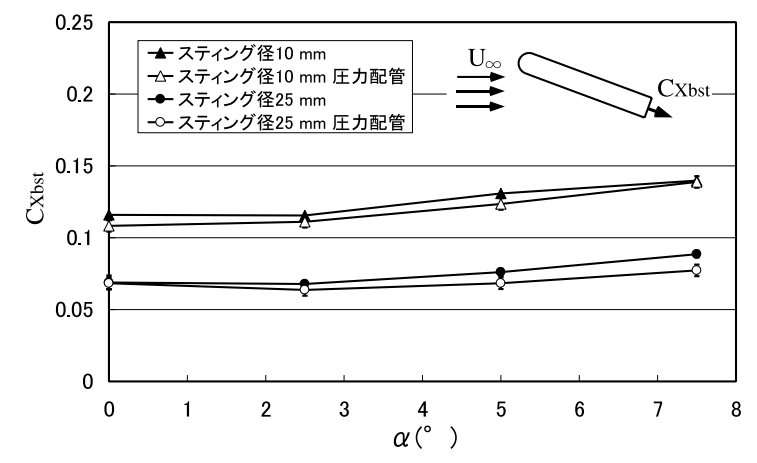

第 9 図 base 圧による軸力係数 $C_{X b_{\mathrm{st}}}$ の比較
支持なし base flat」の base 圧は，弚の他のケースと比較 して，低くなっていることが分かる. 迎角 $0^{\circ}$ の場合，光の 分布は兰れ光れのケースで一樣であったが，迎角 $7.5^{\circ}$ の場 合，一樣ではなくなっていることが分かる．また，スティ ング支持時において，配管により計測されたスティング付 近の base 圧は, 模型底面 base 圧孔で計測した值と異なっ ている.

第 11 図 (b)より，模型底面で計測された base 圧の $y$ 軸 方向分布はほぼ一樣になっていることが分かる．しかしなが ら，「スティング径 $25 \mathrm{~mm}$ 圧力配管」における base 圧係数 は, 模型底面 base 圧孔で計測した「スティング径 $25 \mathrm{~mm}$ の值と異なっている .

これらより，迎角を有した場合，base 圧分布は一樣では なくなり，また，スティング付近の base 圧と光の半径方向 外側における base 圧の值は異なる場合もあり，スティング

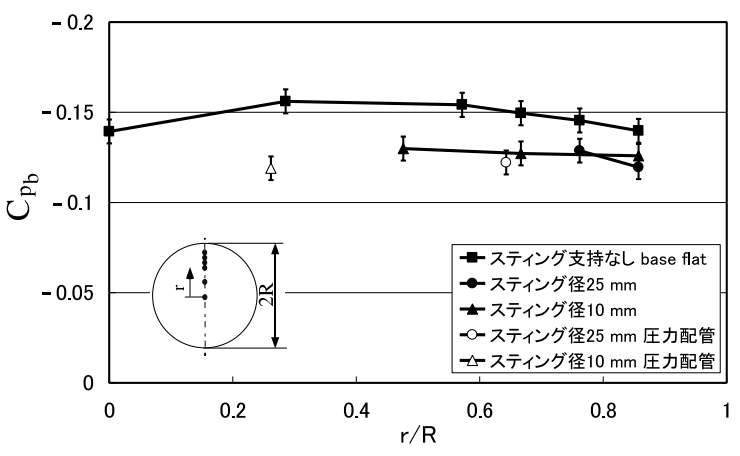

第 10 図 base 圧分布 $\left(\alpha=0^{\circ}\right)$

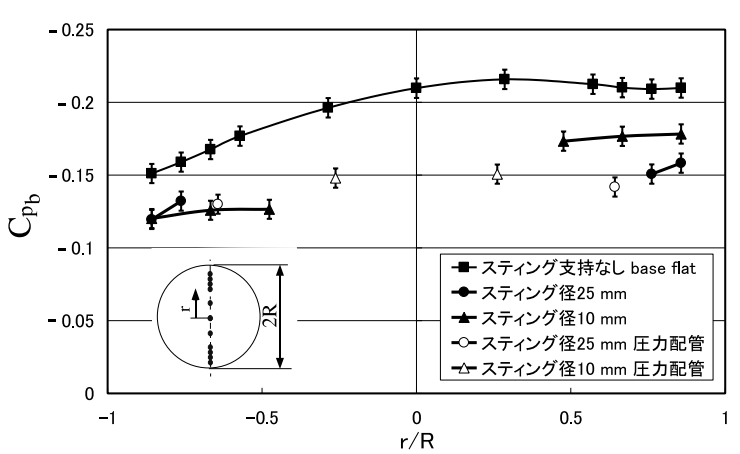

(a) $z$ 軸方向

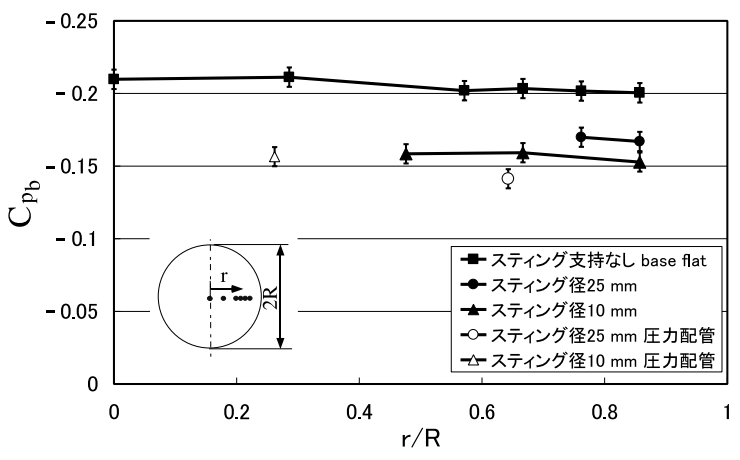

(b) $y$ 軸方向

第11 図 base 圧分布 $\left(\alpha=7.5^{\circ}\right)$ 
付近の base 圧と同樣な base 圧が模型底面全体にもかかる と仮定する base 補正は妥当ではないと考えられる．

このように迎角によって base 圧の分布が一樣でなくなる 原因は, base 面が傾斜することによって, base 背後の再循 環領域が上下非対称に形成されるためであると考えられる また , スティングの径によって , 半径方向外側の base 圧と スティング付近の base 圧の值が滑らかにつながったり，異 なったりする原因は, スティングの径の違いによって，光 の再循環領域の形成や強さが異なるためであると推測され る．しかしながら，兴の原因を解明するには，空間的な流 れ場を把握する必要がある。

3.3 全機軸力を求める base 圧補正について 本研究 で用いた鈍頭模型に対して，低速域における全機軸力推定 のための base 圧による軸力係数推算方法を提案する . こ の方法により，base 圧補正を行うために取得した base 圧 を用いて，スティング支持のない状態での base 圧による 軸力係数を求めることができる. 第 12 図にスティング径 と base 圧による軸力係数の関係を示す. $D_{\mathrm{s}}$ はスティング 直径, $D_{\mathrm{m}}$ は模型底面直径である. 横軸に模型底面直径に 対するスティング径の比 $D_{\mathrm{s}} / D_{\mathrm{m}}$ ，縦軸に弚れ光れの迎角 における「スティング支持においてスティング挿入孔面積 $S_{\mathrm{c}}$ を除いた底面積 $S_{\mathrm{bc}}$ にかかる, base 圧による軸力係数 $\left.C_{X b_{\mathrm{st}}}\right\lrcorner$ を「スティング支持のない状態での base 圧力によ る軸力係数 $\left.C_{X b_{\text {nst }}}\right\lrcorner$ て除した值 $C_{X b_{\text {st }}} / C_{X b_{\text {nst }}}$ を示す。

これより，実験て使用したスティング径が与えられれば， スティング支持なしの場合の軸力係数を推定することがで きる.以下に, base 圧による軸力係数算出及び全機軸力推 定について, 手順を示す。

1) 風洞試験において, 空気力測定と同時に, base 圧によ る軸力係数 $C_{X b_{\mathrm{st}}}$ を, 模型底面に設けた静圧孔より取 得した base 圧より求める.

2) 内挿型天秤などにより測定した軸力係数から $C_{X b_{\mathrm{st}}}$ を 差し引き, forebody 軸力係数を求める.このとき，第 12 図を用いて $C_{X b_{n s t}}$ を算出しておく.

3) 光の forebody 軸力係数に $C_{X b_{\text {nst }}}$ を加え, 全機軸力係 数を求める.

このとき, cavity 圧を含めて補正する場合は, 併せて cavity 圧 $p_{\mathrm{c}}$ も取得しておく必要がある. 光の cavity 圧 $p_{\mathrm{c}}$ を 用いて，第 (5) 式に示すように，スティング支持における

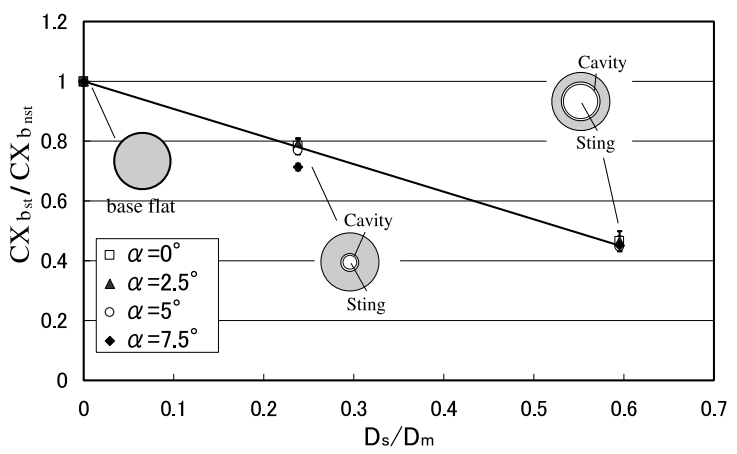

第 12 図 スティング径と base 圧による軸力係数の関係 cavity 面積 $S_{\mathrm{cs}}$ にかかる, cavity 圧による軸力係数 $C_{X b_{\mathrm{cs}}}$ を求める.上述の手順 2) において , 内挿型天秤などにより 測定した軸力係数から $C_{X b_{\mathrm{st}}}$ だけでなく, $C_{X b_{\mathrm{cs}}}$ も差し引 くことにより, forebody 軸力係数を求める.

$$
C_{X b_{\mathrm{cs}}}=-\int_{S_{\mathrm{cs}}}\left(p_{\mathrm{c}}-p_{\infty}\right) \mathrm{d} S / q_{\infty} S_{\mathrm{b}}
$$

この補正を，より精度のよい補正にするためには，樣々 なスティング径と模型底面直径の組み合わせにおいて, 試 験を行うことが重要である．また，補正の一般性を拡張す るためには, 翼の有無などの模型形状やレイノルズ数を変 化させて，さらにパラメトリックにデータを取得すること か望まれる。

\section{4. 結論}

切り立った底部を有する機体の base 圧分布について，ス ティングの有無, スティング径変化及び迎角変化に関して 調べ, base 圧補正法の妥当性を検証するとともに，全機軸 力推定のための base 抵抗推算方法について検討した結果， 以下の結論を得た .

1) スティング装着時, 迎角 $0^{\circ}$ における base 圧分布は 一樣である.しかしながら，迎角を有した場合，base 圧分 布は一樣ではなくなり，また，スティング付近の base 圧と 光の半径方向外側における base 圧の值は異なる場合もあ る．したがって，スティング付近の base 圧と同樣な base 圧か模型底面全体にもかかると仮定する base 補正は，迎角 $0^{\circ}$ においては妥当であるが, 迎角を有した場合は妥当では ない.

2) 本研究で用いた鈍頭模型に対して，低速域において， 全機軸力推定のための base 圧による軸力係数推算方法を提 案した .この方法により，base 圧補正を行うために取得し た base 圧を用いて , スティング支持のない状態での base 圧による軸力係数を求めることができる．また，この方法 は，迎角を考慮したスティング支持がない状態での base 圧 による軸力係数により全機軸力係数を算出することができ るため，全機軸力推定精度が向上すると考えられる．

無線圧力計測システム構築に尽力して下さった九州大学 技術職員の松原 学さん, 貴重な助言をして下さった九州 大学大学院修士課程の西村光正君, 光して磁力支持天秤を 貸与して下さった三菱重工業 (株) 神戶造船所に深く感謝 致します．

\section{参 考 文 献}

1) HYFLEX 空力特性研究チーム: 極超音速飛行実験機 (HYFLEX) の空力特性，航空宇宙技術研究所報告 TR-1334，1997 .

2) NAL/NASDA HOPE 研究共同チーム HYFLEX サブグループ: 極超音速飛行実験機（HYFLEX）の設計結果，航空宇宙技術研 究所報告 TR-1466, 2003.

3) 野田順一, 石田清道, 関根英夫, 原 亘利, 榊原盛三, 河本 巌: 2 台の AGARD-B 標準模型による並列二段式往還機の超音速空 力特性試験，航空宇宙技術研究所資料 TM-692, 1996, p. 36 .

4）青木竹夫,鈴木弘一, 中村正剛,若松逸雄, 中野英一郎:07/HOPE 遷音速対応風洞実験，航空宇宙技術研究所特別資料 SP-38, 1997, 
pp. 139-154.

5）郭 東潤, 宮田勝弘, 野口正芳, 砂田保人, 李家賢一：超音速航 空機 (SST) 形態の高揚力装置に関する実験的研究, 航空宇宙技 術研究所報告 TR-1450，2002．

6) 宮田勝弘, 李家賢一, 郭 東潤, 野口正芳 : 超音速航空機 (SST) 形態の高揚力装置に関する実験的研究 第 2 報 丸い前縁形状の効 果, 航空宇宙技術研究所報告 TR-1456，2003。

7) Kavanau, L. L.: Base Pressure Studies in Rarefied Supersonic Flows, J. Aeronaut. Sci., 23 (1956), pp. 193-207.

8) Jorgensen, L. H.: Prediction of Static Aerodynamic Characteristics for Space-Shuttle-Like and Other Bodies at Angle of Attack from $0^{\circ}$ to $180^{\circ}$, NASA TN D-6996, 1973.

9) Hoerner, S. F.: Fluid-Dynamic Drag, Private Publication, 1958, pp. 3-18-3-22.

10) Britcher, C. P., Alcorn, C. W. and Kilgore, W. A.: Subsonic Sting Interference on the Drag of a Family of Slanted-Base Ogive-Cylinders, AIAA Paper 89-2206-CP, 1989.

11) Tunnel, P. J.: An Investigation of Sting-Support Interference on Base Pressure and Forebody Chord Force at Mach Numbers from 0.60 to 1.30, NACA RM A54K16a, 1955.

12) Cahn, M. S.: An Investigation of Sting-Support Effects on Drag and a Comparison with Jet Effect at Transonic Speeds, NACA Report 1353, 1958.

13) Love, E. S.: A Summary of Information on Support Interference at Transonic and Supersonic Speeds, NACA RM L53K12, 1954.

14) Lee, G., Summers, J. L.: Effects of Sting-Support Interference on the Drag of an Ogive-Cylinder Body with and without a Boattail at 0.6 to 1.4 Mach Number, NACA RM A57I09, 1957.

15) Hart, R. G.: Effects of Stabilizing Fins and a Rear-Support Sting on the Base Pressures of a Body of Revolution in Free Flight at Mach Numbers from 0.7 to 1.3, NACA RM L52E06, 1952.

16) Ericsson, L. E.: Review of Support Interference in Dynamic Tests, AIAA J., 21 (1983), pp. 1652-1666.

17) Koh, J. C. Y.: A New Wind-Tunnel Technique for Providing Simulation of Flight Base Flow, J. Spacecraft Rockets, 8
(1971), pp. 1095-1096.

18) Herrin, J. L. and Dutton, J. C.: Supersonic Base Flow Experiments in the Near Wake of a Cylindrical Afterbody, AIAA J., 32 (1994), pp. 77-83.

19) Merz, R. A., Page, R. H. and Przirenbel, C. E. G.: Subsonic Axisymmetric Near-Wake Studies, AIAA J., 16, 7 (1978), pp. 656-662.

20) 河合宗司，藤井孝蔵：LES/RANS hybrid 手法による亜音速か ら超音速にかけての Base 流れ現象の解明に向けて，第 36 回流 体力学講演会 , 2004, pp. 59-62.

21) Kawai, S. and Fujii, K.: Computational Study of a Supersonic Base Flow Using LES/RANS Hybrid Methodology, AIAA Paper 2004-0068, 2004.

22) Stoney, W. E., Jr.: Pressure Distributions at Mach Numbers from 0.6 to 1.9 Measured in Free Flight on a Parabolic Body of Revolution with Sharply Convergent Afterbody, NACA RM L51L03, 1952.

23）澤田秀夫, 国益徹也 , 須田信一, 溝口也寸志 , 岡田卓三 : JAXA $60 \mathrm{~cm}$ 磁力支持天秤装置の 5 軸天秤較正試験結果，日本航空宇宙 学会論文集 , 52 (2004), pp. 309-315

24）澤田秀夫，国益徹也，須田信一：磁力支持天秤を用いた球の空気 力測定，第 36 回流体力学講演会，2004, pp. 343-346.

25) Barlow, J. B., Rae, W. H. and Pope, A.: Low-Speed Wind Tunnel Testing, Third Edition, John Wiley and Sons, Inc., New York, 1999, pp. 322-325.

26) 谷一郎, 小橋安次郎, 佐藤 浩：流体力学実験法, 岩波書店, 東京, 1977, pp. 266-281.

27) Alcorn, C. W. and Britcher, C. P.: An Experimental Investigation of the Aerodynamic Characteristics of Slanted Base Ogive Cylinders Using Magnetic Suspension Technology, NASA CR-181708, 1988.

28）佐藤淳造：大型風洞壁面効果補正要領，航空宇宙技術研究所資料 TM-237, 1972 .

29) Kline, S. J. and McClintock, F. A.: Describing Uncertainties in Single Sample Experiments, Mech. Eng., 75, 1 (1974), pp. $3-8$.

30) 佐藤 朗 : 計測概論，計量管理協会編，コロナ社，東京，1978, pp. 30-103 